\title{
HANNAH ARENDT AND THE ANCIENTS: PREFACE
}

\author{
MIRIAM LEONARD
}

I

N 2013 SEVERAL INTERNATIONAL CONFERENCES were held to mark the fiftieth anniversary of the publication of Hannah Arendt's Eichmann in Jerusalem, the text, first published in the New Yorker, that turned her into a renowned and in some quarters reviled public intellectual. That publication demonstrated a prescience about our contemporary condition which explains why Arendt remains one of the most provocative interlocutors in discussions about political ideas and realities today. Arendt's relevance to the present has been cemented by the release of a major feature film about her account of the Eichmann trial in 2012. Just a few years later it is with some irony that one might observe that Eichmann has been displaced as the most resonant of Arendt's works. In early 2017, as was widely reported in the press, bookshops ran out of copies of Arendt's original masterwork, The Origins of Totalitarianism. In the run-up to Donald Trump's presidential inauguration, readers had armed themselves with Arendt's historical manual to help them get to grips with the uncanny return of totalitarianism in the age of neo-liberalism.

The striking contemporary relevance of Arendt's work, however, has not blinded scholars to the significance of its ancient dimension. ${ }^{1}$ It is difficult not to be struck by the pervasive reference to antiquity in her political-cum-philosophical treatise The Human Condition. But its presence can also be felt, for instance, in The Origins of Totalitarianism, where Arendt narrates the Dreyfus affair as the unfolding of a Greek tragedy - a trope that she returns to and develops more fully at the start of Eichmann in Jerusalem and in the conclusion of her book On Revolution. Rome, as a number of contributors to this special issue elaborate, also plays a significant role across her oeuvre. ${ }^{2}$ The question of how one should understand this interest in antiquity still requires some thought. One might be tempted to see Arendt's ancients as a continuation of the legacy of German philhellenism and its tenacious grasp on intellectuals in the nineteenth and early twentieth centuries. Certainly it is possible to see Arendt's election of the Greeks as a mark of her debt to Heidegger. ${ }^{3}$ She shares with her former teacher an investment in Greece as an originary moment - one that requires an excavation of modernity to retrieve. Like Heidegger too, her attachment to the ancient world is a conceptual one that never advocates a return to the actualities of ancient life. But to see a

1. See, e.g., Euben 2000 and Taminiaux 2000.

2. See Hammer 2002.

3. On Arendt and Heidegger, see Villa 1996. See also Canovan 1990. 
nod to Heidegger as the ultimate reference of her ancient proclivities would be reductive. Not least because, as a number of the articles reveal, her Greeks are as much Nietzsche's or Marx's as they are Heidegger's. More importantly, it is in her treatment of ancient texts and ancient ideas that Arendt articulates her distance from and rejection of Heidegger and other aspects of the German intellectual tradition. Her crucial turn away from metaphysics toward politics, for instance, is hinged around a reading of Plato rather than a debate with Heidegger. Similarly, her rejection of mortality in favor of natality finds its source in an analysis of antiquity. Arendt's ancients, in other words, do not act as an entry ticket into German culture but as a way for her to develop a distinct and resistant space within a tradition that she inhabits but fundamentally reshapes.

Plurality is a feature of Arendt's work that a number of the articles elaborate, and one undervalued aspect of Arendt's ancients is their surprising plurality. At one level, this might be a surprising claim because the charge of flattening antiquity, of turning the complex and difficult political practices of ancient societies into a nostalgic utopia has often been leveled against her. Nevertheless, one of the aims of this special issue is to make readers attentive to Arendt's less manifest ancient references. To reveal an Arendt who is, for sure, in dialogue with Plato and Aristotle but also with Augustine and Virgil. For all this, it could be argued that her ancients are not plural enough, that her immersion in antiquity remains a limiting dimension of her thought. Her treatment of slavery is a case in point. Although she is aware that the freedoms enjoyed in the polis were predicated on mass enslavement, such a realization does not seem to change her opinion about the ancient city. This seeming indifference to ancient slavery is compounded when she writes approvingly of the American Revolution and completely omits a reference to the Haitian revolution in her survey of political modernity. At the same time, her discussion of Aristotle's doctrine of natural slavery in The Origins of Totalitarianism is the touchstone in her trenchant analysis of the plight of refugees in the Second World War:

This was to a certain extent the plight of slaves, whom Aristotle therefore did not count among
human beings. Slavery's fundamental offense against human rights was not that it took liberty
away [...], but that it excluded a certain category of people from the possibility of fighting for
freedom [...]. Slavery's crime against humanity did not begin when one people defeated and
enslaved its enemies [. . . but when slavery became an institution in which some men were
"born" free and others slave, when it was forgotten that it was man who deprived his fellow-
men of freedom, and when the sanction for the crime was attributed to nature.

Similar questions could be raised about her tacit endorsement of patriarchy. In choosing that most proudly androcentric of political organizations, does Arendt invite us to ally her classicism to her masculinism? As Mary Dietz argues:

Arendt's political vision was decisively (if only metaphorically) Hellenic: the classical Greek polis was her model of the public; Pericles, the Athenian statesman immortalized by Thucydides, was her exemplary citizen-hero; and the quest for freedom as glory through "selfrevelation" in plurality was her political vision. A political theory so seemingly indebted to the ancient Greek culture of masculinity and warrior heroes, and to the classical tradition of

4. Arendt 1976, 317. 
Western thought, was bound to meet with resistance in feminist writings of the $70 \mathrm{~s}$ and $80 \mathrm{~s}$ as participants in the "second wave" began to pursue a woman-centred theory of knowledge and debunk the patriarchal assumptions of "male-stream" Western political thought. ${ }^{5}$

In Dietz's account, it was Arendt's obsessive return to antiquity that made her so unpalatable to her early feminist critics. Arendt's blindness to gender issues was a byproduct of her investment in the hyper-masculine political structures of the classical world. In particular, feminists have pointed out that the rigid distinction that Arendt draws between the public and private realms finds its support in the misogynistic practices of the Athenian democratic polis. ${ }^{6}$ It would follow from such an account that it is in her relationship to antiquity that Arendt is least reflective about questions of gender. And yet, Adriana Cavarero and, more recently, Bonnie Honig have drawn extensively on Arendt in their feminist explorations of Greek tragedy. ${ }^{7}$ In addition to exploring the potential of natality, both Honig and Cavarero in different ways show how Arendt's analysis of action can provide a theoretical framework for a performative understanding of gender which opens up new avenues for exploring the resonance of ancient texts.

Arendt's apparent deafness to the political marginalization of women and slaves poses a challenge to the liberal proclivities of much contemporary classical scholarship. Her provocative writings about tradition and her lionization of a Western canon of ancient thought similarly go against the grain. Arendt's staunch defense of classical culture has been interpreted as an attempt to rescue the writings of antiquity from their crude appropriation in Nazi thought. But, as both Katherine Harloe's and Joy Connolly's pieces in this special issue make clear, Arendt's thinking about the value of historical cultures is more complex than such a defensive stance would suggest. In a quotation from the essay "What Is Authority?," discussed by Connolly, she writes:

\footnotetext{
With the loss of tradition we have lost the thread which safely guided us through the vast realms of the past, but this thread was also the chain fettering each successive generation to a predetermined aspect of the past. It could be that only now will the past open up to us with unexpected freshness and tell us things no one has yet had ears to hear. But it cannot be denied that without a securely anchored tradition - and the loss of this security occurred several hundred years ago - the whole dimension of the past has been endangered. We are in danger of forgetting, and such an oblivion - quite apart from the contents that could be lost-would mean that, humanely speaking, we would deprive ourselves of one dimension, the dimension of depth in human existence. ${ }^{8}$
}

This passage beautifully captures the ambivalent dynamic of the agencies of the present over the present and the past(s) over the present which plays such a distinctive role in Arendt's own relationship to antiquity. Arendt articulates both the compulsion to remember and the freedom that each new generation has in actively recreating the past.

Arendt's profound immersion in antiquity coupled with such self-consciousness about the act of reception make it easy to see why she might be of interest to

5. Dietz 2002, 101

6. For a nuanced account of Arendt's relationship to feminism, see Honig 1995

7. See Cavarero 2000 and Honig 2013.

8. Arendt 2006, 94. 
scholars of classical reception. But Arendt's interest to classicists can and should go beyond that. In a felicitous phrase, Arendt makes the past feel imperative. One of the most valuable aspects of Arendt's work is that she models our interaction with the ancients in political rather than historical terms. Arendt's texts are populated by classical figures, not just Socrates, Plato, and Aristotle, Thucydides and Pericles, but also the nameless demos who inhabit her imagined polis. Arendt's ancients are not historical and in this respect she shares something with other philosophical readers of ancient texts who conduct their conversations with classical authors across the chasm of historical and cultural difference. Nevertheless, Arendt does not treat antiquity as if it were timeless. Rather, she structures the encounter between ancient and modern as a political encounter. The ancient texts intervene into the present as actions rather than actors. The reference to the Greeks and Romans functions for Arendt as a kind of performative. While lacking the depth of historical figures, they nevertheless have a powerful agency that refuses modern appropriation. In fact, it is the singularity of the Greek experience that she wishes to reanimate in the present. The appeal she makes to antiquity in her essay "What Is Freedom?" is exemplary:

Let us therefore go back to antiquity, i.e., to its political and prephilosophical traditions, certainly not for the sake of erudition, not even because of the continuity of our tradition, but merely because a freedom experienced in the process of acting and nothing else - though of course mankind never lost this experience altogether-has never been articulated with the same classical clarity. ${ }^{9}$

Arendt acutely pinpoints how in our discussions of antiquity we too often think about the classical world in terms either of erudition - that is, as a form of historicism - or of continuity. Arendt rejects both those models and in the process shows how in taking refuge in history we displace politics. Being responsive to historical alterity constitutes our responsibility only in a restrictive moral sense. Taking responsibility for antiquity requires returning it to its agency and allowing it to act in the present. Instead of criticizing her overly nostalgic gaze or rebuking her for her historical inaccuracies we do better to value the strategic accessibility Arendt gives us to the past. As Peter Euben writes:

\footnotetext{
we can gain such access because the 'polis' is less a physical entity or specific historical configuration than an ever-present possibility, even under the inhospitable conditions of modernity. The polis, Arendt writes, is 'not the city-state in its physical location; it is the organization of the people as it arises out of acting and speaking together . . no matter where they happen to be.' 10
}

Like Nietzsche, who hoped to enlist the "untimeliness" of antiquity to act on the present and shape the future, Arendt's gift lies in her ability "to press the past into the service of establishing the strangeness of the present."11

The articles in this collection thus do not so much chart the extensive references to antiquity in Arendt's writings as explore the ways that thinking with Arendt can help us reevaluate antiquity in its relationship to modernity. The open-

\footnotetext{
9. Arendt 2006, 163.

10. Euben 2000, 162. The citation is from Arendt 1998, 98.

11. Kateb $1984,149$.
} 
ing paper by Joy Connolly was first delivered at Chicago as the Walsh Lecture in 2016. It looks in detail at Arendt's understanding of the notions of tradition and authority. Connolly discovers in Arendt's references to Rome a parallel for her understanding of thought as by necessity a "two-in-one" activity. The Roman awareness of their relations to others models an ethical relationship to the tradition that can inspire our own engagements with the classical past. Katherine Harloe returns to the problem of authority as she tackles the question of historiography in Arendt and teases out her distinctive stake in the quarrel between ancients and moderns. Arendt emerges from this analysis not just as an opponent of a powerful tradition of German historicism, but as one who engaged deeply with the question of the contemporaneity of the "classical." Harloe thus goes to the heart of the question of whether Arendt's return to antiquity makes her a progressive or a reactionary. Andrew Benjamin, like Connolly, reads Arendt through Rome and shows how Arendt's insistence that "men, not man, live on the earth and inhabit the world" can be read together with Seneca. In particular, he looks at the concept of nudity as an understanding of human dignity and contrasts the Senecan conception to Arendt's own Latin formulation inter homines esse. As in Connolly's contribution, relationality emerges as a key concept from Arendt's writings on antiquity. Finally, Miriam Leonard looks at the ambivalent role that the ancients play in Arendt's understanding of the modern phenomenon of revolution. In Arendt's hands, revolution upends conventional temporality: classical antiquity is both inescapable and not yet fully actualized in the modern experience of political upheaval. In On Revolution, her most hopeful book, the ancients play a crucial role in Arendt's exploration of the risks and the potential of collective action. Taken together, the articles in this collection suggest that Arendt's encounter with the ancients holds the key to understanding some of the most urgent ethical, political, and aesthetic questions of our times.

University College London

\section{LITERATURE CITED}

Arendt, Hannah. 1976. The Origins of Totalitarianism. New ed. with added prefaces. San Diego. 1998. The Human Condition ${ }^{2}$. Chicago.

2006. Between Past and Future: Eight Exercises in Political Thought. London.

Canovan, Margaret. 1990. Socrates or Heidegger? Hannah Arendt's Reflections on Philosophy and Politics. Social Research 57.1: 135-65.

Cavarero, Adriana. 2000. Relating Narratives: Storytelling and Selfhood. London.

Dietz, Mary. 2002. Turning Operations: Feminism, Arendt, Politics. London.

Euben, Peter 2000. Arendt's Hellenism. In Villa 2000, 151-64.

Hammer, Dean. 2002. Hannah Arendt and Roman Political Thought: The Practice of Theory. Political Theory 30.1: 124-49.

Honig, Bonnie 1995. Feminist Interpretations of Hannah Arendt. University Park, PA.

. 2013. Antigone Interrupted. Cambridge.

Kateb, George. 1984. Hannah Arendt: Politics, Conscience, Evil. Totowa, NJ.

Taminiaux, Jacques 2000. Athens and Rome. In Villa 2000, 165-77.

Villa, Dana R. 1996. Arendt and Heidegger: The Fate of the Political. Princeton, NJ. , ed. 2000. The Cambridge Companion to Hannah Arendt. Cambridge. 